\title{
A Pharmacokinetic and Pharmacodynamic Drug Interaction Study of Acamprosate and Naltrexone
}

\author{
Barbara J. Mason, Ph.D., Anita M. Goodman, M.D., Russell M. Dixon, M.D., \\ Magdy H. Abdel Hameed, Ph.D., Thierry Hulot, Pharm.D., Keith Wesnes, Ph.D., \\ John A. Hunter, M.S., and Michael G. Boyeson, Ph.D.
}

Acamprosate and naltrexone have each demonstrated safety and efficacy for alcohol dependence in placebo-controlled clinical trials. There is scientific and clinical interest in evaluating these drugs in combination, given their high tolerability, moderate effect sizes, different pharmacological profiles and potentially different effects on drinking outcomes. Thus, this is the first human pharmacokinetic and pharmacodynamic drug interaction study of acamprosate and naltrexone. Twenty-four normal, healthy adult volunteers participated in a double-blind, multiple dose, within subjects, randomized, 3-way crossover drug interaction study of the standard therapeutic dose of acamprosate $(2 \mathrm{~g} / d)$ and the standard therapeutic dose of naltrexone $(50 \mathrm{mg} / \mathrm{d})$, given alone and in combination, with seven days per treatment condition and seven days washout between treatments. Blood samples were collected on a standardized schedule for pharmacokinetic analysis of naltrexone, 6- $\beta$-naltrexol, and acamprosate. A computerized assessment system evaluated potential drug effects on cognitive functioning. Coadministration of acamprosate with naltrexone significantly increased the rate and extent of absorption of acamprosate, as indicated by an average $33 \%$ increase in acamprosate maximum plasma concentration, $33 \%$ reduction in time to maximum plasma concentration, and $25 \%$ increase in area under the plasma concentration-time curve. Acamprosate did not affect the pharmacokinetic parameters of naltrexone or 6 - $\beta$-naltrexol. A complete absence of negative interactions on measures of safety and cognitive function supports the absence of a contraindication to co-administration of acamprosate and naltrexone in clinical practice.

[Neuropsychopharmacology 27:596-606, 2002] (C) 2002 American College of Neuropsychopharmacology. Published by Elsevier Science Inc.
KEY WORDS: Pharmacodynamics; Pharmacokinetics; Alcohol; Naltrexone; Acamprosate; Cognition

From the Division of Substance Abuse, Department of Psychiatry and Behavioral Sciences, University of Miami School of Medicine, Miami, FL (BJM), Lipha Pharmaceuticals, Inc., New York, NY (AMG), Covance Clinical Research Unit, Madison, WI (RMD, MHAH, MGB, JAH), Lipha s.a., Lyon, France (TH), and Cognitive Drug Research Limited, Reading, UK (KW).

Address correspondence to: Barbara Mason, Alcohol Disorders Research Unit, 1400 N.W. 10th Avenue, Suite 307A, Miami, FL

33136. Tel.: (305) 243-4059; E-mail: bjmason246@aol.com

Received February 12, 2002; revised April 18, 2002; accepted April 22, 2002.

Online publication: 5/7/02 at www.acnp.org/citations/Npp 050702298
Recent efforts to develop pharmacological interventions for relapse-prevention in newly abstinent alcoholics initially focused on acamprosate (Campral $\AA$, Aotal $₫$ ) in Europe and naltrexone (ReVia () in the United States of America. Acamprosate and naltrexone have each demonstrated efficacy and safety in randomized, double-blind, placebo-controlled trials in alcohol-dependent outpatient volunteers (Garbutt et al. 1999; Litten and Allen 1998; Mason 2001; Mason and Ownby 2000; Swift 1999). Neither medication interacts with alcohol or has abuse potential or rebound effects when discontinued. Despite these similarities, acamprosate and naltrexone induce their action via very different mecha- 
nisms and may affect different behavioral aspects of alcohol dependence.

Acamprosate is a centrally acting synthetic analog of the naturally occurring amino acid neuromediator taurine (Dahchour and de Witte 2000). Chronic alcohol exposure is associated with decreased GABAergic transmission and increased glutamate activity (Grant et al. 1990; Hoffman and Tabakoff 1994). Although the precise mechanism of action or cellular target of acamprosate is not fully elucidated, acamprosate appears to modulate $N$-methyl- $D$-aspartate (NMDA) receptor activity in the glutamate system, and to inhibit the upregulation of voltage-gated $\mathrm{Ca}^{2+}$ channels that is induced by chronic alcohol ingestion and states of withdrawal (Allgaier et al. 2000; Popp and Lovinger 2000). Thus, acamprosate may act on neurobiological mechanisms that may persist for many months following alcohol withdrawal, and that may contribute to the vulnerability for drinking relapse (Borg 1988).

The clinical safety and efficacy of acamprosate was evaluated in 16 placebo-controlled, double-blind trials of 3,6, or 12 months duration conducted across $11 \mathrm{Eu}$ ropean countries and involving more than 4,500 male and female outpatients with alcohol dependence (Barrias et al. 1997; Besson et al. 1998; Chick et al. 2000a; Geerlings et al. 1997; Gual and Lehert 2001; Ladewig et al. 1993; Lhuintre et al. 1985, 1990; Paille et al. 1995; Pelc et al. 1992, 1997; Poldrugo 1997; Rousseaux et al. 1996; Sass et al. 1996; Tempesta et al. 2000; Whitworth et al. 1996). Fourteen of 16 trials showed a significant advantage for acamprosate over placebo on abstinence measures. There are no serious or rate-limiting adverse effects associated with acamprosate. Mild and transient diarrhea is the only drug-related adverse event that differed consistently from placebo across studies. Acamprosate is not metabolized. It is eliminated by the kidneys and is contra-indicated in cases of renal insufficiency (Saivin et al. 1998). Oral acamprosate tablets are available by prescription in 39 countries, with about 1.5 million people treated with acamprosate worldwide. The Food and Drug Administration granted Investigational New Drug status for acamprosate, and a 21-site, 6-month, double-blind placebo-controlled dose-ranging trial has recently been completed in 601 alcohol-dependent outpatients in support of USA regulatory approval (for methodology see Mason and Ownby 2000).

Naltrexone is a highly selective opioid antagonist (Chang et al. 1979). A large body of pre-clinical studies suggests that endogenous opioids play a role in the reinforcing effects of alcohol, and that blockade of these receptors with an antagonist decreases the positive reinforcing effects of alcohol and reduces drinking (Koob et al. 1998). These findings suggest that an opioid antagonist may not initially prevent sampling of alcohol (i.e., promote abstinence), but may reduce risk of relapse to excessive drinking in subjects who sample alcohol while taking an opioid antagonist. Double-blind placebo-controlled clinical trials with naltrexone and a structural analog, nalmefene, provide support for the use of opioid antagonists for reducing relapse severity in persons with alcohol dependence (Anton et al. 1999; Mason et al. 1999; O'Malley et al. 1992; Oslin et al. 1997; Volpicelli et al. 1992, 1997), although some recent trials have been inconclusive (Chick et al. 2000b; Kranzler et al. 2000; Krystal et al. 2001). A multicenter safety study found naltrexone to be well tolerated with patients complaining primarily of headache and nausea that tended to be transient in nature (Croop et al. 1997). Naltrexone is metabolized by the hepatic cytosolic enzyme system to form 6- $\beta$-naltrexol, a major pharmacologically active metabolite (Porter et al. 2000). It is contraindicated in cases of hepatic insufficiency (Sifton 1997).

With drugs for a common indication where the overall effect size is moderate and there are not overlapping toxicities, it is of interest to explore whether or not coadministration may enhance clinical outcome. There is considerable interest in evaluating the safety of combined administration of acamprosate and naltrexone given the high tolerability of each drug, their different pharmacological profiles (glutamate vs. opiate), potentially different effects on drinking outcomes (e.g., increased abstinence duration vs. decreased relapse severity), and the increasing world-wide availability of both compounds. The objectives of this study are to determine if there is a pharmacokinetic (PK) or pharmacodynamic (PD) drug interaction between acamprosate and naltrexone in normal, healthy adult subjects. Chronic heavy alcohol intake and some pharmacological agents selective for either opioid or NMDA receptors have been associated with changes in memory and cognition (Chaves et al. 1988; Cohen et al. 1983; Kathmann et al. 1996; Malenka 1991; O'Mahony and Doherty 1996; Parsons and Farr 1981; Schneider et al. 1999; Willetts et al. 1990). Therefore, evaluation of a pharmacodynamic drug interaction will focus on tests of cognitive functioning.

\section{METHODS}

\section{Subjects}

Subjects were normal, healthy male and female paid volunteers. The study was conducted under appropriate guidelines for the protection of human subjects, in accordance with the Declaration of Helsinki. To be eligible, subjects had to be 18 to 40 years of age; weigh at least 110 pounds and be within $15 \%$ of their normal body weight for height; have negative results on hepatitis panel, HIV antibody, urine drug and alcohol, and pregnancy (if female) tests; and provide written in- 
formed consent. Subjects were excluded if they met current Diagnostic and Statistical Manual Fourth Edition (American Psychiatric Association 1994) criteria for alcohol or other drug use disorders, including nicotine and opiates; had clinically relevant medical or psychiatric disorders; used any prescribed medications within two weeks prior to study entry, except contraceptives; used over-the-counter preparations within one week prior to study entry, except vitamins which could be continued at the same dosage; used any alcohol, caffeine or xanthine-containing products within $72 \mathrm{~h}$ prior to the first dose of study drug for each treatment period; were pregnant, lactating, or refused to use a reliable method of contraception.

\section{Study Procedures}

This was a double-blind, multiple-dose, within subjects, randomized 3-way crossover interaction study of the standard therapeutic doses of acamprosate $(2 \mathrm{~g} / \mathrm{d})$ and naltrexone $(50 \mathrm{mg} / \mathrm{d})$, given alone and in combination. All subjects received all three treatment conditions in an order determined by a computer-generated randomization code. Subjects were admitted to the inpatient clinical research unit on the day prior to the first dose administration and were discharged after completion of study procedures on Day 11, for each treatment condition. Steady state levels of acamprosate are achieved by the seventh day of dosing (Wilde and Wagstaff 1997). Therefore, in order to adequately test for drug interactions, all subjects were dosed with each study medication for seven days and completed PK and PD studies through Day 11 (Hansten and Horn 1993). The 7-day treatment periods were separated with at least a 7-day washout period to avoid carryover drug effects from the previous treatment condition.

\section{Treatment Conditions}

Treatment conditions were: (1) acamprosate 1000-mg (two 500-mg tablets manufactured by Groupe Lipha) administered orally every $12 \mathrm{~h}$, starting at 7:00 A.M., for a total of 13 doses, plus one naltrexone placebo capsule administered orally once daily at 7:00 A.M., for a total of seven doses; (2) two acamprosate placebo tablets administered orally every $12 \mathrm{~h}$ starting at 7:00 A.M., for a total of 13 doses, plus one 50-mg naltrexone tablet (one 50-mg ReVia ${ }^{\circledR}$ tablet manufactured by DuPont Pharma, over-encapsulated to match naltrexone placebo) administered orally once daily at 7:00 A.M. for a total of seven doses; and (3) acamprosate $1000 \mathrm{mg}$ (two 500-mg tablets) administered orally every $12 \mathrm{~h}$ starting at 7:00 A.M., for a total of 13 doses, plus a 50-mg naltrexone tablet administered orally every $24 \mathrm{~h}$ starting at 7:00 A.M., for a total of seven doses. A mouth check was performed by Unit staff to verify that the dose was swallowed. All doses were taken with $240 \mathrm{~mL}$ of water thirty minutes prior to consumption of standardized meals, except for Day 7 (PK day) when subjects fasted for $4.5 \mathrm{~h}$ post dose. On Day 7, subjects also remained ambulatory, i.e., standing or seated, for $4 \mathrm{~h}$ post dose. Use of concomitant medication during the study was prohibited unless pre-approved or necessary in a medical emergency. Any such use and the reason was documented.

\section{Safety and Tolerability}

Clinical laboratory evaluations (hematology, clinical chemistry (fasting), and urinalysis) were performed at screening and during each treatment period at check-in, on Day 2 (24 h after first dose of study drug), on Day 8 (24 h after last dose of study drug), and on Day 11 (prior to each clinic discharge). A serum ( $\beta-\mathrm{HCG}$ ) pregnancy test was performed for females at screening, at each check-in day, and at study completion (Day 11 of Period 3). A urine screen for drugs of abuse (including alcohol, amphetamines, barbiturates, benzodiazepines, cannabinoids, cocaine, methadone, opiates, phencyclidine and propoxyphene) was performed at screening and repeated at each check-in. Complete physical and neurological examinations were performed at screening, with follow-up exams at check-in and Days 7, 8, and 11 of each treatment period. A 12-lead ECG was obtained at screening, check-in of Period 1, and at study completion (Day 11 of Period 3). Vital signs were obtained at screening, at check-in, on Days 1 through 10, prior to and 3 and $6 \mathrm{~h}$ following the morning dose, and prior to inpatient discharge on Day 11. In conjunction with vital sign measurement at pre-dose on Days 1 through 10 and on Day 11, subjects were asked "Have there been any changes in the way you feel since the last time you were asked?"

Adverse events were recorded using the Coding Symbols for Thesaurus of Adverse Reaction Terms (Department of Health and Human Services 1995) terminology from check-in through study completion. All adverse events, whether spontaneously reported by the subject or observed by study personnel, were documented along with any medical intervention, and evaluated according to standardized criteria in terms of severity, frequency, duration and causal relationship to study medication.

\section{Pharmacokinetic Parameters}

Acamprosate has no biologically active metabolites. The activity of naltrexone is due to both the parent and 6- $\beta$ naltrexol metabolite (Meyer et al. 1984). Separate blood samples for PK analysis of acamprosate and for PK analysis of naltrexone and 6- $\beta$-naltrexol were collected during each treatment period as follows: Day 1 prior to the 
first dose of study drug, i.e., baseline; Days 5 and 6, premorning dose, i.e, PK trough concentrations; Day 7 premorning dose and $0.5,1.0,1.5,2,3,4,6,8,10,12,24,36$, 48,72 , and $96 \mathrm{~h}$ after the Day 7 morning dose.

\section{Bioanalytical Methods}

Naltrexone and 6- $\beta$-naltrexol plasma concentrations were measured using a validated high performance liquid chromatographic mass spectrometric analytical method with a lower limit of quantification set at 0.25 ng/mL (Beyerlein and Polywacz 1998). The variability of back-calculated concentrations of calibration standards ranged from $4.0 \%$ to $9.4 \%$ for naltrexone. The between-day precision was determined at levels of 0.750 , $7.50,80.0$ and $250 \mathrm{ng} / \mathrm{mL}$ in replicate analyses $(\mathrm{n}=36$, 36, 60 and 12, respectively). The between-day variability did not exceed $14.3 \%$. The relative standard deviation (RSD) for the back-calculated concentration for naltrexone was $5.4 \%$ with a deviation of $-1.2 \%$ from the theoretical concentration. For 6- $\beta$-naltrexol, the RSD for the back-calculated concentration was $3.4 \%$ with a deviation of $0.5 \%$ from the theoretical concentration.

Acamprosate plasma concentrations were measured by a validated gas chromatography/negative ion chemical ionization mass spectrometry method with a lower limit of quantification of $3.12 \mathrm{ng} / \mathrm{mL}$ (Girault et al. 1990). At this level, the precision (\% RSD) and accuracy (mean percentage of error), calculated from 10 replicate samples were equal to $4.36 \%$ and $0.87 \%$ respectively. The between-day precision was determined at levels of $6.25,50$, and $400 \mathrm{ng} / \mathrm{mL}$ in replicate analyses. The RSD values were lower than $6.53 \%$ and the accuracy was between $-0.83 \%$ and $2.45 \%$.

For each subject, the following pharmacokinetic parameters were determined for naltrexone, $6-\beta$-naltrexol, and acamprosate using plasma concentration-time profiles on Day 7 according to the model independent approach with Win Nonlin Professional Version 1.5 software (Scientific Consultant, Inc.): maximum observed (peak) concentration $\left(\mathrm{C}_{\max }\right)$; time to maximum concentration $\left(\mathrm{T}_{\max }\right)$; degree of fluctuation at steady state $(\mathrm{DF})$; area under the plasma concentration-time curve over one dosing interval, i.e., from hours 0 to 12 for acamprosate and hours 0 to 24 for naltrexone and 6- $\beta$-naltrexol, estimated by linear trapezoidal rule $\left(\mathrm{AUC}_{\mathrm{o}-\tau}\right)$; and apparent plasma terminal phase elimination half-life $\left(\mathrm{T}_{1 / 2}\right)$.

\section{Tests of Cognitive Functioning}

A pharmacodynamic drug interaction was evaluated with the Cognitive Drug Research computerized assessment system that assesses drug effects on various parameters of cognitive functioning, e.g., word recall, word recognition, attention and reaction time (Wesnes et al. 1991, 1994, 2000). All tasks are computer-con- trolled, with stimuli presented on high-resolution monitors, and the responses recorded via two buttons, one marked 'NO' and the other 'YES'.

Tasks assessing reaction time (Simple Reaction Time, Choice Reaction Time) or speed of performance (Numeric Working Memory, Delayed Word Recognition) were measured in milliseconds. Tasks assessing the accuracy of performance (Immediate and Delayed Word Recall, Digit Vigilance) were scored as the percent of possible correct responses. Additionally, a Sensitivity Index was calculated for Numeric Working Memory and Delayed Word Recognition in which the ability to identify previously presented items was assessed relative to the ability to correctly reject "distracter" items which were not previously presented. A score of 1 represents perfect sensitivity to the task information: all previously presented items are correctly identified and all distracter items are rejected as novel. A score of zero represents chance performance or insensitivity to task information.

Subjects completed four training sessions. Subjects were tested during each treatment period at check in, on Days 1, 3, and 7 at pre-dose, 4 and $7 \mathrm{~h}$ post-dose, and on Day 11 prior to discharge. Parallel forms of tests were presented in each testing session to control for practice effects. As a secondary endpoint, results from the 4-hour post-dose testing session were evaluated in relation to PK effects from the same timepoint.

\section{Sample Size Determination}

A primary objective of this study was to test for a pharmacokinetic drug interaction between oral doses of acamprosate and naltrexone. Sample size calculations for acamprosate were based on summarized data from a 2-way crossover study of repeated doses of acamprosate using within-subject variability data (Lipha Pharmaceuticals, Inc. 1996). Naltrexone calculations were based on summarized data from a 4-way crossover study of varying doses of naltrexone using between-subject variability data (Meyer et al. 1984). A sample size of 24 in a crossover design which uses within-subject variance as compared with the between-subject variance of other designs was estimated to have at least $90 \%$ power $(\alpha=0.05)$ to detect mean percentage changes of $20 \%$ for acamprosate AUC and $20 \%$ for naltrexone AUC.

\section{Statistical Analyses}

Statistical significance for selected pharmacokinetic parameters was assessed using an analysis of variance (ANOVA) model with terms for sequence, subject within sequence, period, and treatment. In addition to ANOVAs on untransformed data, ANOVAs were done on natural $\log (\ln )$ transformed $\mathrm{C}_{\max }$ and $\mathrm{AUC}_{\mathrm{o}-\tau}$ data. The $\ln$-transformed results were the pivotal criterion 
used to draw conclusions regarding drug interaction, and due to large variability in $\mathrm{C}_{\max }, \mathrm{AUC}_{\mathrm{o}-\tau}$ was the primary variable analyzed. Since the $T_{\max }$ data were not normally distributed, they were compared using the Friedman's nonparametric test (Sokal and Rohlf 1995).

To assess if naltrexone or 6- $\beta$-naltrexol had an effect on acamprosate and if acamprosate had an effect on naltrexone or 6- $\beta$-naltrexol, per FDA recommendations, $90 \%$ confidence intervals (two 1-sided tests) were computed for the difference between the test (co-dosing) and reference (acamprosate or naltrexone alone) values for $C_{\max }$ and $A U C_{o-\tau}$ (Steinijans et al. 1991). For $C_{\max }$ and $\mathrm{AUC}_{\mathrm{o}-\tau}$, no drug interaction effect was assumed if the $90 \%$ confidence interval was between $80 \%$ and $120 \%$. For the Ln-transformed $\mathrm{C}_{\max }$ and $\mathrm{AUC}_{\mathrm{o}-\tau}$, no drug interaction effect was assumed if the $90 \%$ confidence interval was between $80 \%$ and $125 \%$.

Steady state levels of acamprosate are achieved by the seventh day of dosing. Therefore, the trough concentrations $\left(C_{\min }\right)$ observed on Days 5,6 , and 7 were compared by ANOVA to check the equilibrium achievement.

To test for pharmacodynamic drug interactions between acamprosate and naltrexone, the pre-dose cognitive assessment on Day 1 was used as a baseline, and subtracted from subsequent scores to derive difference from baseline scores. The post-dose difference scores were then subject to an ANOVA, terms being fitted for treatment, the repeated assessments, and the interaction between the treatment conditions and repeated assessments. Where the main effect or the interaction was significant, the least squares means procedure was used to make multiple comparisons between the conditions to identify where the differences lay.

Fisher exact test probabilities were calculated for frequency analysis of adverse drug experiences between test and reference groups.

All statistical tests were two-sided and had an $\alpha$ level of .05.

\section{RESULTS}

\section{Subjects}

Twenty-five subjects entered the study, and 24 completed all three treatment periods. One subject became noncompliant with meal and daily task requirements in the first treatment period and was replaced with a subject who completed the three treatments in the originally assigned sequence. Data for the replaced subject were included in the demographic and safety analysis. The double-blind was maintained for all subjects across all treatment conditions. Subjects (19 males and six females) were a mean age of 31.8 ( \pm 5.2) years, 175.3 ( \pm $8.9) \mathrm{cm}$ tall, and $74.5( \pm 8.9) \mathrm{kg}$ in weight. The sample consisted of 23 Caucasian, one Hispanic, and one African American subject.

\section{Acamprosate Pharmacokinetics}

Coadministration of naltrexone significantly enhanced the rate and extent of acamprosate bioavailability, resulting in significantly shorter acamprosate $\mathrm{T}_{\max }$ and higher $\mathrm{C}_{\max }$ values, in comparison with administration of acamprosate alone (Table 1). Acamprosate median $\mathrm{T}_{\max }$ values were $6.0 \mathrm{~h}$ following dosing alone and $4.0 \mathrm{~h}$ following dosing in combination with naltrexone $(p<$ .01). The mean acamprosate $\mathrm{C}_{\max }$ when administered in combination with naltrexone $(517 \mathrm{ng} / \mathrm{mL}$ ) was approximately $33 \%$ higher than the mean $C_{\max }$ when administered alone (390 ng/mL, $p<.01)$, and the $90 \%$ confidence interval for the test/reference ratio for the ln-transformed $\mathrm{C}_{\max }(120 \%$ to $156 \%)$ was not entirely contained within the $80 \%$ to $125 \%$ range, indicating that administration of acamprosate in combination with naltrexone significantly increased the rate of absorption of acamprosate.

The mean acamprosate $\mathrm{AUC}_{\mathrm{o}-\tau}$ when administered in combination with naltrexone $(4,658 \mathrm{ng} \mathrm{hr} / \mathrm{mL})$ was approximately $25 \%$ greater than the mean $\mathrm{AUC}_{\mathrm{o- \tau}}$ when acamprosate was administered alone $(3,734 \mathrm{ng} \mathrm{hr} / \mathrm{mL})$. Likewise, the $90 \%$ confidence interval for the test/reference ratio for the $\mathrm{Ln}$-transformed $\mathrm{AUC}_{\mathrm{o}-\mathrm{T}}(114 \%$ to $143 \%)$ was not entirely contained within the $80 \%$ to $125 \%$ range, indicating that administration of acamprosate in combination with naltrexone significantly improved the absorption of acamprosate (Figure 1).

Naltrexone did not significantly affect the elimination half-life of acamprosate. Acamprosate was slowly eliminated following oral administration with mean $\mathrm{T}_{1 /}$ ${ }_{2}$ values of 18.5 and $17.9 \mathrm{~h}$ when administered alone or in combination with naltrexone, respectively.

Steady-state was verified for acamprosate by ANOVA of trough concentrations from Days 5, 6 and 7, both when administered alone (Day $5=264 \pm 128.4$ $\mathrm{ng} / \mathrm{mL}$, Day $6=271 \pm 123.7 \mathrm{ng} / \mathrm{mL}$, Day $7=256 \pm$ $120.9 \mathrm{ng} / \mathrm{mL}, \mathrm{F}_{2,23}=0.48, p=.62$ ) and in combination with naltrexone (Day $5=336 \pm 153.0 \mathrm{ng} / \mathrm{mL}$, Day $6=$ $332 \pm 148.5 \mathrm{ng} / \mathrm{mL}$, Day $7=344 \pm 147.4 \mathrm{ng}, \mathrm{mL} \mathrm{F}_{2,23}=$ $0.18, p=.83)$.

\section{Naltrexone and 6- $\beta-$ Naltrexol Pharmacokinetics}

Co-administration of acamprosate and naltrexone had no effect on the pharmacokinetics of naltrexone and its metabolite, $6-\beta$-naltrexol. The $90 \%$ confidence intervals for the Ln-transformed $C_{\max }$ and AUC for naltrexone and 6- $\beta$-naltrexol are entirely contained within the 80 $125 \%$ range (Table 1, Figure 2). Acamprosate also had no effect on the elimination half life of naltrexone or 6$\beta$-naltrexol.

Steady state analysis was only performed for $6-\beta-$ naltrexol, as all the trough concentrations for naltrexone, which has an elimination half life of about $4 \mathrm{~h}$ (Table 1), were below the limit of quantitation. Steady state 
Table 1. Pharmacokinetic (PK) Drug Interaction Analyses of Acamprosate, Naltrexone and 6- $\beta$-Naltrexol Plasma Data Within Subjects $(\mathrm{n}=24)^{*}$

\begin{tabular}{|c|c|c|c|c|c|}
\hline PK Parameter & Test & Reference & $\begin{array}{c}\text { Percent } \\
\text { Test/Reference }\end{array}$ & $\begin{array}{c}90 \% \\
\text { Confidence } \\
\text { Interval }\end{array}$ & $\begin{array}{c}p \text { value } \\
\text { Treatment }\end{array}$ \\
\hline \multicolumn{6}{|l|}{ Acamprosate } \\
\hline $\mathrm{AUC}_{\mathrm{o}-\tau}(\mathrm{ng} \mathrm{hr} / \mathrm{mL})$ & $4658 \pm 1778.2$ & $3734 \pm 1644.2$ & 125 & $(112,137)$ & $<.01$ \\
\hline $\ln A U C_{0-\tau}$ & 4277 & 3349 & 128 & $(114,143)$ & $<.01$ \\
\hline $\mathrm{C}_{\max }(\mathrm{ng} / \mathrm{mL})$ & $517 \pm 183.6$ & $390 \pm 160.0$ & 133 & $(118,148)$ & $<.01$ \\
\hline $\ln C_{\max }$ & 482 & 353 & 137 & $(120,156)$ & $<.01$ \\
\hline $\mathrm{T}_{\max }$ (Hour) & $4.00(0-12.0)$ & $6.00(0-12.0)$ & NA & NA & .03 \\
\hline $\mathrm{T}_{1 / 2}$ (Hour) & $17.9 \pm 8.81$ & $18.5 \pm 14.9$ & 119 & NA & .09 \\
\hline \multicolumn{6}{|l|}{ Naltrexone } \\
\hline $\mathrm{AUC}_{\mathrm{o}-\tau}(\mathrm{ng} \mathrm{hr} / \mathrm{mL})$ & $38.0 \pm 16.07$ & $38.6 \pm 16.53$ & 98.4 & $(90.1,107)$ & 0.74 \\
\hline $\ln A U C_{o-\tau}$ & 35.1 & 35.5 & 98.9 & $(92.0,106)$ & 0.79 \\
\hline $\mathrm{C}_{\max }(\mathrm{ng} / \mathrm{mL})$ & $11.0 \pm 4.76$ & $11.8 \pm 6.55$ & 93.3 & $(79.6,107)$ & 0.41 \\
\hline $\ln C_{\max }$ & 10.0 & 10.4 & 96.2 & $(85.0,109)$ & 0.60 \\
\hline $\mathrm{T}_{\max }$ (Hour) & $1.00(0.5-3.01)$ & $1.00(0.5-2.0)$ & NA & NA & 0.20 \\
\hline $\mathrm{T}_{1 / 2}$ (Hour) & $3.58 \pm 1.63$ & $4.02 \pm 3.49$ & 89.1 & NA & 0.57 \\
\hline \multicolumn{6}{|l|}{ 6- $\beta$-Naltrexol } \\
\hline $\mathrm{AUC}_{\mathrm{o}-\tau}(\mathrm{ng} \mathrm{hr} / \mathrm{mL})$ & $779 \pm 128.3$ & $788 \pm 134.8$ & 98.8 & $(95.0,103)$ & 0.60 \\
\hline $\ln A U C_{0-\tau}$ & 769 & 777 & 98.9 & $(95.4,103)$ & 0.61 \\
\hline $\mathrm{C}_{\max }(\mathrm{ng} / \mathrm{mL})$ & $91.3 \pm 19.34$ & $96.1 \pm 21.05$ & 95.0 & $(87.2,103)$ & 0.29 \\
\hline $\ln C_{\max }$ & 89.4 & 94 & 95.1 & $(88.1,103)$ & 0.27 \\
\hline $\mathrm{T}_{\max }$ (Hour) & $1.00(0.5-3.0)$ & $1.00(0.5-2.0)$ & NA & NA & 1.0 \\
\hline $\mathrm{T}_{1 / 2}$ (Hour) & $15.1 \pm 4.18$ & $14.7 \pm 3.88$ & 103 & NA & 0.51 \\
\hline
\end{tabular}

*Values given are means \pm standard deviations, except for $\mathrm{T}_{\max }$ values for which the median and range are given. P-value for difference between treatment means from ANOVA, except $\mathrm{T}_{\max } \mathrm{P}$-value is from Friedman's nonparametric test.

Test $=$ combination treatment with acamprosate and naltrexone. Reference $=$ naltrexone treatment for naltrexone and 6- $\beta$-naltrexol PK parameters, and acamprosate treatment for acamprosate PK parameters. $C_{\max }=$ maximum observed (peak) plasma concentration. $T_{\max }=$ time to maximum plasma concentration.

$\ln =$ Natural $\log$ transformed. $\mathrm{AUC}_{\mathrm{o}-\tau}=$ area under the plasma concentration-time curve during one dosing interval from pre-dose. $\mathrm{T}_{1 / 2}=$ terminal phase elimination half-life.

was achieved for 6- $\beta$-naltrexol, which has an elimination half life of about $15 \mathrm{~h}$ (Table 1 ), when naltrexone was administered alone (Day $5=13.4 \pm 14.4 \mathrm{ng} / \mathrm{mL}$, Day $6=14.4 \pm 4.2 \mathrm{ng} / \mathrm{mL}$, Day $7=14.3 \pm 3.5 \mathrm{ng}, \mathrm{mL}$, $\mathrm{F}_{2,23}=2.49, p=.09$ ). However, for the combination of acamprosate and naltrexone, steady state was not verified (Day $5=13.8 \pm 3.7 \mathrm{ng} / \mathrm{mL}$, Day $6=13.7 \pm 3.6 \mathrm{ng} /$ $\mathrm{mL}$, Day $\left.7=14.5 \pm 3.9 \mathrm{ng}, \mathrm{mL}, \mathrm{F}_{2,23}=4.78, p=.01\right)$. The 15 -hour half life of $6-\beta$-naltrexol and seven days of verified dosing were sufficient to achieve steady state. However, there were considerable within and between subject fluctuations in naltrexone plasma concentrations in both the single drug $(\mathrm{DF}=702 \% \pm 156.9)$ and co-dosing conditions ( $\mathrm{DF}=721 \% \pm 190.6)$, as is typical in a drug that is subject to extensive first-pass metabolism (Meyer et al. 1984). Degree of fluctuation (DF) in 6- $\beta$ naltrexol plasma concentrations was marked in both the single drug $(\mathrm{DF}=251 \% \pm 55.8)$ and co-dosing conditions $(\mathrm{DF}=240 \% \pm 51.6)$. In contrast, acamprosate DF was relatively small under both the single drug $(\mathrm{DF}=48.5 \% \pm$ 37.8 ) and co-dosing conditions ( $\mathrm{DF}=38.9 \% \pm 21.9$ ).

Dissolution profiles were equivalent for the over encapsulated naltrexone tablets compared with the standard ReVia ${ }^{\circledR}$ naltrexone tablets.

\section{Cognitive Testing to Assess Pharmacodynamic Drug Interaction}

Naltrexone alone was associated with significantly slower performance speed than acamprosate alone or when dosed in combination with acamprosate on two attentional tasks: Choice Reaction Time $\left(\mathrm{F}_{2,23}=5.04, p=.007\right)$ and Digit Vigilance Speed $\left(\mathrm{F}_{2,23}=4.23, p=.015\right)$ (see Table 2 for pairwise comparisons). Naltrexone alone was also associated with significantly lower sensitivity on Delayed Word Recognition than acamprosate alone or when dosed in combination with acamprosate $\left(\mathrm{F}_{2,23}=\right.$ $6.43, p=.002)$. Acamprosate alone was associated with a significant drop in Immediate Word Recall accuracy relative to naltrexone alone $\left(\mathrm{F}_{2,23}=3.70, p=.025\right)$. Conversely, acamprosate alone was associated with significantly faster performance speed on Delayed Word Recognition than naltrexone alone or when dosed in combination with naltrexone $\left(\mathrm{F}_{2,23}=4.46, p=.002\right)$. There were no performance deficits associated with the combined treatment condition relative to naltrexone alone or acamprosate alone on any cognitive assessments. Furthermore, there were no significant interactions between repeated cognitive assessments over time and treatment condition, i.e., there were differences between the treat- 


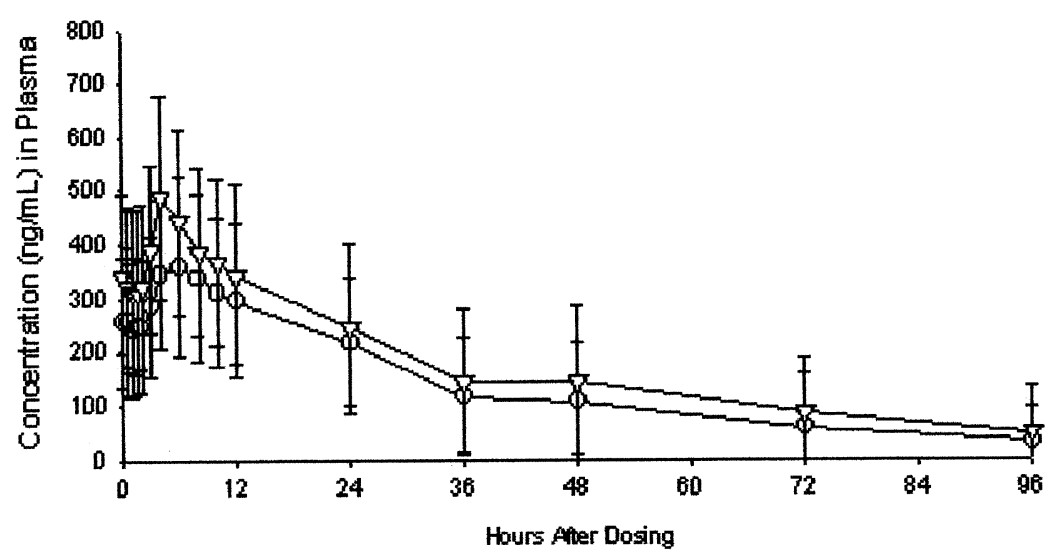

Figure 1. Mean concentration $(\mathrm{ng} / \mathrm{mL})$ of acamprosate in human plasma (linear scale).

\section{- - Acamprosate \\ $\rightarrow$ Acamprosate conourrent with Naltrexone}

ment conditions, but the differences did not depend on the duration of dosing.

Relationships between drug plasma concentration levels and cognitive data were evaluated as secondary endpoints by subjecting the coinciding Day 7 Hour 4 plasma concentrations and cognitive assessments to correlation analysis. A positive correlation was found with acamprosate alone on the Delayed Word Recognition Sensitivity Index $(r=0.45, p=.03)$. No other relationship between PK and PD variables was detected.

\section{Safety and Tolerability}

A summary of adverse events reported by $>15 \%$ ( $\geqslant 4$ of 25) subjects is presented in Table 3 . There were no differences in the rates of adverse drug events across treatment conditions, and no subject discontinued the study due to side effect complaints. Nineteen percent of all adverse events were judged as probably unrelated to study medication, $65 \%$ as possibly related, and $15 \%$ as probably related. There were no adverse events rated as severe and $94 \%$ of all adverse events were rated as mild in severity. There were no clinically significant abnormalities observed on any laboratory parameter nor on physical examination, and no clinically significant changes in vital signs or ECG measurements.

\section{COMMENT}

Coadministration of acamprosate and naltrexone was well tolerated by subjects, with no clinically or statistically significant drug-related adverse events.

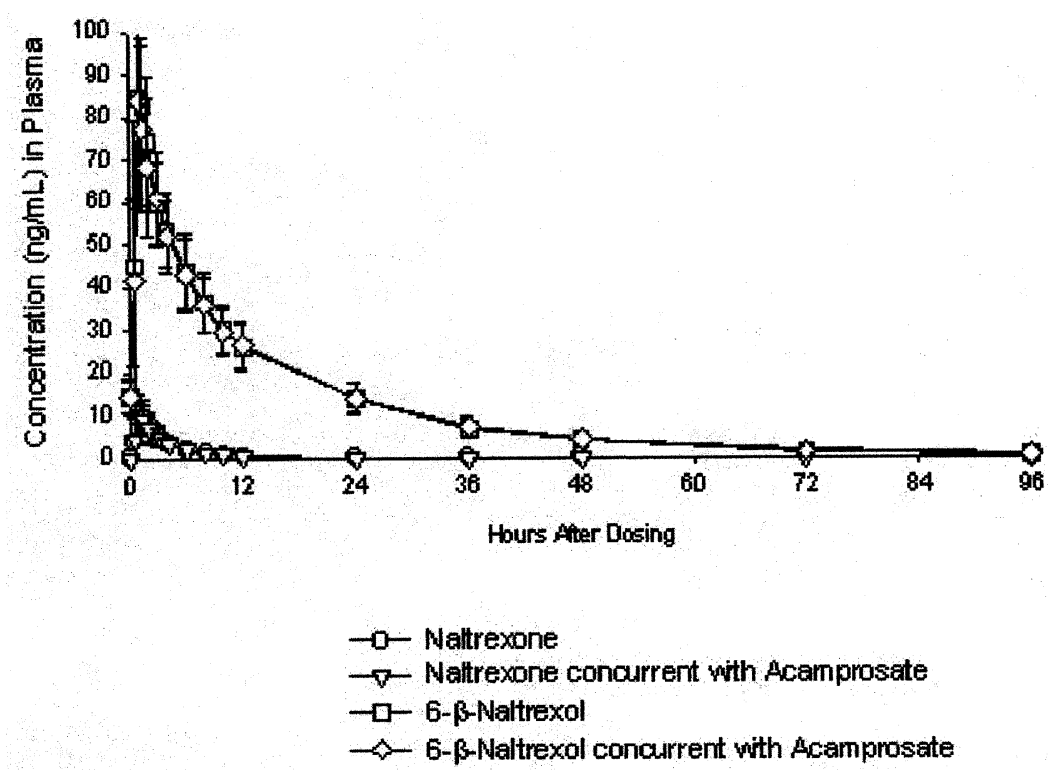

Figure 2. Mean concentration $(\mathrm{ng} / \mathrm{mL})$ of naltrexone and 6- $\beta$-naltrexol in human plasma (linear scale). 
Table 2. Within Subjects Change from Baseline on Each Test of Cognitive Function in Each Treatment Condition $(\mathrm{N}=24)^{*}$

\begin{tabular}{|c|c|c|c|}
\hline & Acamprosate & Naltrexone & $\begin{array}{l}\text { Acamprosate } \\
\text { and Naltrexone }\end{array}$ \\
\hline Simple Reaction Time & $17.4 \pm 3.5$ & $15.5 \pm 3.5$ & $21.9 \pm 3.5$ \\
\hline Choice Reaction Time (msec) & $6.4 \pm 3.7$ & $22.5 \pm 3.7^{\mathrm{a}, \mathrm{b}}$ & $10.2 \pm 3.7$ \\
\hline \multicolumn{4}{|l|}{ Digit Vigilance } \\
\hline Accuracy (\%) & $-1.16 \pm 0.4$ & $-0.4 \pm 0.4$ & $-0.0 \pm 0.4$ \\
\hline Speed (msec) & $9.6 \pm 2.4$ & $17.5 \pm 2.4^{\mathrm{a}, \mathrm{b}}$ & $8.1 \pm 2.4$ \\
\hline \multicolumn{4}{|l|}{ Numeric Working Memory } \\
\hline Sensitivity Index & $-0.03 \pm 0.1$ & $-0.05 \pm 0.1$ & $-0.05 \pm 0.1$ \\
\hline Speed (msec) & $-10.4 \pm 6.5$ & $6.9 \pm 6.5$ & $-2.2 \pm 6.5$ \\
\hline Immediate Word Recall-Accuracy (\%) & $-3.0 \pm 0.9^{c}$ & $0.3 \pm 0.9$ & $-1.4 \pm 0.9$ \\
\hline Delayed Word Recall-Accuracy (\%) & $-1.6 \pm 1.0$ & $-2.5 \pm 1.0$ & $-2.1 \pm 1.0$ \\
\hline \multicolumn{4}{|l|}{ Delayed Word Recognition } \\
\hline Sensitivity Index & $-0.03 \pm 0.01$ & $-0.07 \pm 0.01^{\mathrm{a}, \mathrm{b}}$ & $-0.00 \pm 0.01$ \\
\hline Speed (msec) & $-37.7 \pm 7.6^{\mathrm{b}, \mathrm{c}}$ & $-2.3 \pm 7.6$ & $-7.0 \pm 7.6$ \\
\hline
\end{tabular}

*Values given are least squares means \pm standard error of the mean. An ANOVA was applied to each cognitive measure and when the main effect of treatment condition was significant, the least squares means procedure was used to make multiple comparisons between treatment conditions to identify where the significant differences lay.

${ }^{\mathrm{a}} p<.05$ vs. acamprosate alone

${ }^{\mathrm{b}} p<.05$ vs. acamprosate and naltrexone combined

$c_{p}<.05$ vs. naltrexone alone

There was a statistically significant pharmacokinetic interaction when the standard therapeutic dose of acamprosate $(2 \mathrm{~g} / \mathrm{d})$ was administered in combination with the standard therapeutic dose of naltrexone (50 mg once daily) for seven days. Coadministration of naltrexone with acamprosate significantly increased the rate and extent of absorption of acamprosate, as indicated by the $33 \%$ shorter $\mathrm{T}_{\max }$ values, $33 \%$ increase in acamprosate $C_{\max }$, and the $25 \%$ increase in the $\mathrm{AUC}_{\mathrm{o}-\mathrm{\tau}}$.

Acamprosate is not metabolized and is primarily renally excreted (Saivin et al. 1998). Naltrexone is primarily metabolized by hepatic cytosolic enzymes (Porter et al. 2000). Thus, acamprosate does not share a metabolic pathway with naltrexone and, therefore, an hepatic isozyme interaction is not likely to account for the PK interaction observed in the present study.

One hypothesis to explain the increased plasma levels of acamprosate with naltrexone coadministration is some change in gastrointestinal function, given the well known interaction of opiate and opiate-like drugs with gut opioid receptors. Acamprosate tablets have an enteric coating, such that acamprosate is absorbed in the intestine, not the stomach. Opioid antagonists have been shown to affect gastrointestinal transit and may thereby influence acamprosate absorption (Aurich et al. 1993; Krevsky et al. 1990). There are few studies on the mechanism of acamprosate absorption and results are not definitive. Saivin et al. (1998) summarized a series of studies in healthy human volunteers and concluded that acamprosate is primarily absorbed via the paracellular route in the gastrointestinal tract, and poorly bound on caco-2 cells. Mas-Serrano et al. (2000) conducted a series of experiments to characterize the intes- tinal transport of acamprosate in the rat, and concluded that there are probably two pathways involved: passive diffusion, and to a much less extent, a carrier system, i.e, the amino-acid carrier. The work presented by Saivin et al. (1998) and Mas-Serrano et al. (2000) suggest there are at least three potential mechanisms through which a drug interaction may enhance acamprosate absorption: (1) by increasing membrane permeability if transport occurs by the paracellular route; (2) by using surfactants as promoters if diffusion takes place by the transcellular route; and (3) by inhibition of a specialized secretion transport that limits bioavailability and functions as a barrier to absorption. Further work on the mecha-

Table 3. Adverse Events Reported by $>15 \%$ ( $\geqslant 4$ of 25 ) of Subjects*

\begin{tabular}{lccc}
\hline & Acamprosate & Naltrexone & $\begin{array}{c}\text { Acamprosate } \\
\text { and Naltrexone }\end{array}$ \\
\hline Headache & 3 & 7 & 4 \\
Nausea & 5 & 8 & 7 \\
Asthenia & 0 & 4 & 3 \\
Diarrhea & 4 & 2 & 3 \\
Dizziness & 1 & 3 & 4 \\
Thinking & & & \\
$\quad$ abnormal & 3 & 2 & 3 \\
Pain & 0 & 2 & 3 \\
Anorexia & 1 & 4 & 3 \\
Vomiting & 3 & 0 & 36 \\
Flatulence & 1 & 3 & 2 \\
Total & 23 & 36 & \\
\hline
\end{tabular}

*Values given are the actual number of subjects reporting an adverse event. There were no statistically significant differences between treatments. 
nism of acamprosate absorption and the pharmacokinetic interaction with naltrexone is warranted.

The clinical relevance of the pharmacokinetic interaction was not assessed in the current study. However, prior human studies show a linear relationship with acamprosate $C_{\max }, A U C$, and oral dose (data on file, Lipha Pharmaceuticals, Inc. 1996), and clinical dose-ranging studies support a linear dose-effect on treatment outcomes (Paille et al. 1995; Pelc et al. 1997). Therefore, the increased absorption of acamprosate when coadministered with naltrexone may predict greater efficacy for the combination than standard dosing with either drug alone. Additionally, naltrexone could hypothetically speed the onset of action of acamprosate by shortening acamprosate $\mathrm{T}_{\max }$.

Cognitive testing found that negative or positive changes in performance from baseline associated with the administration of each drug alone were consistently normalized back to baseline levels with co-dosing. Naltrexone alone had some capacity to reduce attentional efficiency and sensitivity in word recognition. This latter finding is consistent with early work showing impairment by naltrexone and naloxone, another opioid antagonist, on verbal memory tasks (Chaves et al. 1988; Cohen et al. 1983).

In the present study, acamprosate alone reduced immediate word recall accuracy, but produced an increase in the speed of delayed word recognition. Additionally, the Delayed Word Recognition Sensitivity Index was positively correlated with the concentration of acamprosate in plasma in the acamprosate alone condition. NMDA receptors are involved with long-term potentiation, an electrophysiological phenomena involving longlasting, activity-dependent increases in the strength of synaptic transmission, which appears to be an intermediate step required for memory storage (Malenka 1991). Recent evidence suggests that acamprosate may act as a partial co-agonist at the NMDA receptor (Naassila et al. 1998; al Qatari et al. 1998). The acamprosate cognitive data are consistent with pre-clinical and human studies that show d-cycloserine, a partial agonist of the glycine site on the NMDA receptor, did not affect acquisition of new learning, but did improve performance during the retention phase of tasks (Jones et al. 1991; Pussinen et al. 1997; Tsai et al. 1999; Wesnes et al. 1991).

The cognitive findings in the present study are unlikely to be accounted for by the intrusion of side effects, given that side effects did not differ across groups, and $94 \%$ were rated as mild in severity. Rather, the different pharmacodynamic profiles of acamprosate and naltrexone found on cognitive testing support the view that these drugs operate via different neural pathways and mechanisms. From a clinical perspective, these changes in performance from baseline were detected in a statistically powerful within subjects design, but the magnitude of the differences are small, i.e., 1030 milliseconds in mean performance speed, or recall of approximately one word, over an entire task sequence as per prior reports (Schneider et al. 1999).

The complete absence of any negative interaction between acamprosate and naltrexone chronically administered in standard therapeutic doses is supportive of the absence of a contraindiction to their co-utilization in clinical practice.

\section{ACKNOWLEDGMENTS}

This study was conducted under an IND held by Lipha Pharmaceuticals, Inc., the sponsor of the study and the manufacturer of acamprosate. Acamprosate, naltrexone and matched placebo were provided by the study sponsor. Dr. Mason serves as consultant to Lipha Pharmaceuticals, Inc. and Forest Laboratories, Inc. and receives research support from DuPont Pharma, Inc., the manufacturer of naltrexone. The authors would like to thank Judy Lozano for her help with manuscript preparation and Mike Arends for his editorial assistance.

\section{REFERENCES}

Allgaier C, Franke H, Sobottka H, Scheibler P (2000): Acamprosate inhibits $\mathrm{Ca}+$ influx mediated by NMDA receptors and voltage-sensitive $\mathrm{Ca} 2+$ channels in cultured rat mesencephalic neurones. Naunyn-Schmiedebergs Arch Pharmacol 362:440-443

al Qatari M, Bouchenafa O, Littleton J (1998): Mechanism of action of acamprosate. Part II Ethanol dependence modifies effects of acamprosate on NMDA receptor binding in membranes from rat cerebral cortex. Alcohol Clin Exp Res 22:810-814

American Psychiatric Association (1994): Diagnostic and Statistical Manual of Mental Disorders, Revised Fourth Edition. Washington, DC, American Psychiatric Press

Anton RF, Moak DH, Waid LR, Latham PK, Malcolm RJ, Dias JK (1999): Naltrexone and cognitive behavioral therapy for the treatment of outpatient alcoholics: results of a placebo-controlled trial. Am J Psychiatry 156:1758-1764

Aurich C, Aurich JE, Klug E (1993): Naloxone affects gastrointestinal functions and behaviour in horses. Dtsch Tieraztl Wochenschr 100:314-315

Barrias JA, Chabac S, Ferreira L, Fonte A, Potgieter AS, Teixeira de Sousa E (1997): Acamprosate: multicenter Portuguese efficacy and tolerance evaluation study. Psiquiatria Clinica 18:149-160

Besson J, Aeby F, Kasas A, Lehert P, Potgieter A (1998): Combined efficacy of acamprosate and disulfiram in the treatment of alcoholism: a controlled study. Alcohol Clin Exp Res 22:573-579

Beyerlein D, Polywacz J (1998): Method validation for the determination of naltrexone and 6-b-naltrexol in human plasma by high-performance liquid chromatography with MS/MS detection. Covance 2100-131. Madison, WI, Covance Laboratories, Inc.

Borg S (1988): Biochemical and clinical features in alcoholic 
patients during long-term abstinence and prior to relapse. Alcohol Alcohol 23:515-526

Chang K-J, Cooper BR, Hazum E, Cuatrecasas P (1979): Multiple opiate receptors: Different regional distribution in the brain and differential binding of opiates and opioid peptides. Mol Pharmacol 16:91-104

Chaves ML, Bizzi JW, Palmini AL, Izquierdo I (1988): Naltrexone blocks the enhancing effect of novel experiences on performance in memory tests in humans. Neuropsychologia 26:491-494

Chick J, Howlett H, Morgan MY, Ritson B (2000a): United Kingdom multicentre acamprosate study (UKMAS): a 6 month prospective study of acamprosate versus placebo in preventing relapse after withdrawal from alcohol. Alcohol Alcohol 35:176-187

Chick J, Anton R, Checinski K, Croop R, Drummond DC, Farmer R, Labriola D, Marshall J, Moncrieff J, Morgan MY, Peters T, Ritson B (2000b): A multicentre, randomized, double-blind, placebo-controlled trial of naltrexone in the treatment of alcohol dependence or abuse. Alcohol Alcohol 35:587-593

Cohen RM, Cohen MR, Weingartner H, Pickar D, Murphy DL (1983): High-dose naloxone affects task performance in normal subjects. Psychiatry Res 8:127-136

Croop RS, Faulkner EB, Labriola DF (1997): The safety profile of naltrexone in the treatment of alcoholism. Arch Gen Psychiatry 54:1130-1135

Dahchour A, de Witte P (2000): Ethanol and amino acids in the central nervous system: assessment of the pharmacological actions of acamprosate. Prog Neurobiol 60:343-362

Department of Health and Human Services (1995): COSTART: Coding Symbols for Thesaurus of Adverse Reaction Terms, 5th ed. Washington, DC, U.S. Government Printing Office

Garbutt JC, West SL, Carey TS, Lohr KN, Crews FT (1999): Pharmacological treatment of alcohol dependence: a review of the evidence. JAMA 281:1318-1325

Geerlings PJ, Ansoms C, van den Brink W (1997): Acamprosate and prevention of relapse in alcoholics. Eur Addict Res 3:129-137

Girault J, Gobin P, Fourtillan JB (1990): Determination of calcium acetylhomotaurinate in human plasma and urine by combined gas chromatography-negative ion chemical ionization mass spectrometry. J Chromatography Biomedical Appl 530:295-305

Grant KA, Valverius P, Hudspith M, Tabakoff B (1990): Ethanol withdrawal seizures and the NMDA receptor complex. Eur J Pharmacol 176:289-296

Gual A, Lehert P (2001): Acamprosate during and after acute alcohol withdrawal: a double-blind, placebo-controlled study in Spain. Alcohol Alcohol 36:413-418

Hansten PD, Horn JR. (1993): Pharmacokinetic drug interaction mechanisms and clinical characteristics. Vancouver, Washington: Drug Interactions and Updates Quarterly, Applied Therapeutics, Inc., pp 1-24, 119, 121.

Hoffman PL, Tabakoff B (1994): The role of the NMDA receptor in ethanol withdrawal. Experientia 71:61-70

Jones RW, Wesnes KA, Kirby J (1991): Effects of NMDA modulation in scopolamine dementia. Ann NY Acad Sci 640:241-244
Kathmann N, Soyka M, Gallinat J, Hegerl U (1996): Effects of acamprosate on verbal learning in healthy young subjects. In Soyka M (ed), Acamprosate in Relapse Prevention of Alcoholism. New York, Springer-Verlag, pp 105-110

Koob GF, Roberts AJ, Schulteis G, Parsons LH, Heyser CJ, Hyytia P, Merlo-Pich E, Weiss F (1998): Neurocircuitry targets in ethanol reward and dependence. Alcohol Clin Exp Res 22:3-9

Kranzler HR, Modesto-Lowe V, Van Kirk J (2000): Naltrexone vs. nefazodone for treatment of alcohol dependence: a placebo-controlled trial. Neuropsychopharmacol 22:493-503

Krevsky B, Fisher RS, Cowan A (1990): Failure of (+) - naloxone to accelerate feline colonic transit. Experientia 46: 217-219

Krystal JH, Cramer JA, Krol WF, Kirk GF, Rosenheck RA (2001): Naltrexone in the treatment of alcohol dependence. Veterans Affairs Naltrexone Cooperative Study 425 Group. N Engl J Med 345:1734-1739

Ladewig D, Knecht T, Lehert P, Fendl A (1993): Acamprosate - a stabilizing factor in the long-term treatment of alcoholics. Ther Umsch 50:182-188

Lhuintre JP, Daoust M, Moore ND, Chretien P, Saligaut C, Tran G, Boismare F, Hillemand B (1985): Ability of calcium bis acetyl homotaurine, a GABA agonist, to prevent relapse in weaned alcoholics. Lancet 1:1014-1016

Lhuintre JP, Moore ND, Tran G, Steru L, Langrenon S, Daoust M, Parot P, Ladure P, Libert C, Boismare P, Hillemand B (1990): Acamprosate appears to decrease alcohol intake in weaned alcoholics. Alcohol Alcohol 25: 613-622

Lipha Pharmaceuticals, Inc. (1996): Final report on comparative bioavailability study to compare pharmacokinetic parameters under steady state conditions of two acamprosate treatments $(666 \mathrm{mg}$ acamprosate t.i.d. vs. $1000 \mathrm{mg}$ acamprosate b.i.d.) in 24 healthy male volunteers. Data on file 23 .

Litten RZ, Allen JP (1998): Advances in development of medications for alcoholism treatment. J Psychopharmacol 139:20-33

Malenka RC (1991): The role of postsynaptic calcium in the induction of long-term potentiation. Molecular Neurobiology 5:289-295

Mason BJ, Ownby RL (2000): Acamprosate for the treatment of alcohol dependence: a review of double-blind, placebo-controlled trials. CNS Spectrums 5:58-69

Mason BJ (2001): Treatment of alcohol-dependent outpatients with acamprosate: a clinical review. J Clin Psychiatry 62 (suppl. 20):42-48

Mason BJ, Salvato FR, Williams LD, Ritvo EC, Cutler RB (1999): A double-blind, placebo-controlled study of oral nalmefene for alcohol dependence. Arch Gen Psychiatry 56:719-724

Mas-Serrano P, Granero L, Martin-Algarra RV, Guerri C, Polache A (2000): Kinetic study of acamprosate absorption in rat small intestine. Alcohol Alcohol 35:324-330

Meyer MC, Straughn AB, Lo MW, Schary WL, Whitney CC (1984): Bioequivalence, dose proportionality and pharmacokinetics of naltrexone after oral administration. J Clin Psychiatry 45:15-19 
Naassila M, Hammoumi S, Legrand E, Durbin P, Daoust M (1998): Mechanism of action of acamprosate: Part I Characterization of spermidine-sensitive acamprosate binding site in rat brain. Alcohol Clin Exp Res 22:802-809

O'Mahony JF, Doherty B (1996): Intellectual impairment among recently abstinent alcohol abusers. Br J Clin Psychol 35:77-83

O'Malley SS, Jaffe AJ, Change G, Schottenfeld RS, Meyer RE, Rounsaville B (1992): Naltrexone and coping skills therapy for alcohol dependence: a controlled study. Arch Gen Psychiatry 49:881-887

Oslin D, Liberto JG, O’Brien J, Krois S, Norbeck J (1997): Naltrexone as an adjunctive treatment for older patients with alcohol dependence. Am J Geriatr Psychiatry 5:324-332

Paille F, Guelfi JD, Perkins AC, Royer RJ, Steru L, Parot P (1995): Double-blind randomized multicentre trial of acamprosate in maintaining abstinence from alcohol. Alcohol Alcohol 30:239-247

Parsons OA, Farr SP (1981): The neuropsychology of alcohol and drug use. In Filskov SB and Boll TJ (eds), Handbook of Clinical Neuropsychology. New York, John Wiley and Sons, pp 320-365

Pelc I, Verbanck P, Le Bon O, Gavrilovic M, Lion K, Lehert P (1997): Efficacy and safety of acamprosate in the treatment of detoxified alcohol-dependent patients: a 90-day placebo-controlled dose-finding study. Br J Psychiatry 171:73-77

Pelc I, Le Bon O, Verbanck P, Lehert PH, Opsomer L (1992): Calcium acetyl homotaurinate for maintaining abstinence in weaned alcoholic patients: a placebo controlled double-blind multi-centre study. In Naranjo C, Sellers EM (eds), Novel Pharmacological Interventions for Alcoholism. New York, Springer Verlag, pp 348-352

Poldrugo F (1997): Acamprosate treatment in a long-term community-based alcohol rehabilitation programme. Addiction 92:1537-1546

Popp RL, Lovinger DM (2000): Interaction of acamprosate with ethanol and spermine on NMDA receptors in primary cultured neurons. Eur J Pharmacol 394:221-231

Porter SJ, Somogyi AA, White JM (2000): Kinetics and inhibition of the formation of $6-\beta$-naltrexol from naltrexone in human liver cytosol. Br J Clin Pharmacol 50:465-471

Pussinen R, Nieminen S, Koivisto E, Haapalinna A, Riekkinen P, Sirvio J (1997): Enhancement of intermediateterm memory by an alpha- 1 agonist or a partial agonist at the glycine site of the NMDA receptor. Neurobiol Learn Mem 67:69-74

Rousseaux JP, Hers D, Ferauge M (1996): Does acamprosate diminish the appetite for alcohol in weaned alcoholics? J Pharm Belg 51:65-68

Sass H, Soyka M, Mann K, Zieglgansberger W (1996): Relapse prevention by acamprosate: results from a placebo-controlled study on alcohol dependence. Arch Gen Psychiatry 53:673-680

Saivin S, Hulot T, Chabac S, Potgieter A, Durbin P, Houin G
(1998): Clinical pharmacokinetics of acamprosate. Clin Pharmacokinet 35:331-345

Schneider U, Wohlfarth K, Schulze-Bonhage A, Haacker T, Muller-Vahl KR, Zedler M, Becker H, Dengler R, Emrich HM (1999): Effects of acamprosate on memory in healthy young subjects. J Stud Alcohol 60:172-175

Sifton DW (ed) (1997): Physicians' Desk Reference, 51st ed. Montvale, NJ, Medical Economics Company, pp 957-959

Sokal RR, Rohlf FJ (1995): Biometry: The Principles and Practice of Statistics in Biological Research, 3rd ed. San Francisco, W.H. Freeman, pp 440-442

Steinijans VW, Hartmann M, Huber R, Radtke HW (1991): Lack of pharmacokinetic interaction as an equivalence problem. Intl J Clin Pharmacol Ther and Toxicol 29:323-328

Swift RM (1999): Drug therapy for alcohol dependence. N Engl J Med 340:1482-1490

Tempesta E, Janiri L, Bignamini A, Chabac S, Potgieter A (2000): Acamprosate and relapse prevention in the treatment of alcohol dependence: a placebo-controlled study. Alcohol Alcohol 35:202-209

Tsai GE, Falk WE, Gunther J, Coyle JT (1999): Improved cognition in Alzheimer's disease with short-term D-cycloserine treatment. Am J Psychiatry 156:467-469

Volpicelli JR, Alterman AI, Hayashida M, O’Brien CP (1992): Naltrexone in the treatment of alcohol dependence. Arch Gen Psychiatry 49:876-880

Volpicelli JR, Rhines KC, Rhines JS, Volpicelli LA, Alterman AI, O'Brien CP (1997): Naltrexone and alcohol dependence: role of subject compliance. Arch Gen Psychiatry 54:737-742

Wesnes K, Jones RW, Kirby J (1991): The effects of D-cycloserine, a glycine agonist, in a human model of the cognitive deficits associated with ageing and dementia. Br J Clin Pharmacol 31:577P-578P

Wesnes K, McEwen J, Pritchard G (1994): The dose and time dependent profile of cognitive impairments of alcohol in young volunteers. J Clin Pharmacol 34:1021

Wesnes KA, Garratt C, Wickens M, Gudgeon A, Oliver S (2000): Effects of sibutramine alone and with alcohol on cognitive function in healthy volunteers. Br J Clin Pharmacol 49:110-117

Whitworth A, Fischer F, Lesch OM, Nimmerrichter A, Oberbauer $\mathrm{H}$, Platz T, Potgieter A, Walter H, Fleischhacker WW (1996): Comparison of acamprosate and placebo in long-term treatment of alcohol dependence. Lancet 347:1438-1442

Wilde MI, Wagstaff AJ (1997): Acamprosate: a review of its pharmacology and clinical potential in the management of alcohol dependence after detoxification. Drugs 53: 1038-1053

Willetts J, Balster RL, Leander JD (1990): The behavioral pharmacology of NMDA receptor antagonists. Trends Pharmacol Sci 11:423-428 